\title{
The struggle continues
}

\section{The fight against corruption in prisons}

\section{LUKAS MUNTINGH}

lmuntingh@uwc.ac.za

Following a briefing by the Special Investigating Unit (SIU) to the Portfolio Committee on Correctional Services regarding its investigations into corruption, fraud and maladministration in the Department of Correctional Services (DCS), this was one journalist's response: 'Members of parliament were stunned by a report on the endemic nature of corruption in the Department of Correctional Services, detailing cases of tender rigging, medical aid fraud and petrol card abuse' (De Lange 2008). The report to Parliament raises a number of questions: Is this department irredeemably beyond salvation? What still needs to be done and what is being done to prevent and combat corruption? Are there any successes? These questions are explored in this article.

Successful approaches to fighting corruption are not aimed at removing the proverbial rotten apple from the barrel, but at tackling the barrel itself (Van der Beken 2002:273). Therefore, the aim of the DCS should be to fix the system that creates the conditions for corrupt acts to be committed. Prison systems are by their nature not transparent, and the risk of officials operating with little restraint or accountability is therefore considerable.

Institutions such as these have been referred to as 'calm biopes' - 'areas in which, with organisation and control, corruption structures develop, grow and prosper over the years' (Nötzel 2002:51). Good governance and anti-corruption measures intend to prevent such 'calm biopes' from developing in organisations and to prevent officials from controlling organisations or parts thereof that they might otherwise attempt to exploit for private gain.
The DCS has a special relationship with the SIU, but the assistance from the SIU should be seen as only one pillar of the anti-corruption effort of the DCS, the other three pillars being prevention, public awareness, and institution building (Pope 1999). As important as investigations and law enforcement are, they remain components of a strategy that must address the problem holistically. The key question then is whether sufficient progress has been made to disturb the 'calm biopes' and ensure that there is no safe haven for officials intent on misusing their public office for private gain.

\section{THE SIGNIFICANCE OF PRISON CORRUPTION}

Corruption in the prison system holds particular significance. Failing to address it holds severe 
risks (for taxpayers and victims), but also undermines the very integrity of the penal system by eroding the intended just and morally justifiable punishment of the offender. The prison serves a particular moral function in society and, if there is to be any hope that the prisoner will perceive his or her punishment as justly administered, should execute its task to the highest possible standard, untainted by dishonesty or even impressions of impropriety (Muntingh 2006b:6).

For analytical purposes it is important to distinguish between types of corruption present in the prison system. They can be categorised by three fundamental relationships: between warders and prisoners, between warders (as employees) and the DCS as employer, and between external agents, officials and the department (Muntingh 2006a:19).

\section{THE DCS, DIU AND THE SIU}

\section{Special Investigations Unit}

Following the initial work of the Jali Commission, the Department of Correctional Services and the Special Investigations Unit entered into a threeyear agreement in October 2002 that was later extended to 2006. The first agreement was focused on particular problem areas, namely the medical aid fund, corruption at prisons, management of DCS pharmacies, First Auto card fraud, and mismanagement of assets (Portfolio Committee on Correctional Services 2008). The second three-year agreement was entered into in 2006 with a particular focus on procurement (as the DCS is in the process of entering into a number of large contracts) and asset management, with particular reference to DCS farms. ${ }^{1}$

Although it has not been confirmed by the SIU or the DCS, the so-called 'large contracts' are understood to refer to the installation of security technology, security fencing and nutritional services (Du Plessis 2006).

The results of the DCS-SIU agreement have to date been impressive: R34,9m was recovered (this includes R5,6m in assets under restraint); savings amounting to R3,4b were secured; disciplinary action was recommended in 1183 cases; criminal action was recommended in 327 cases; and ten professionals (primarily doctors) were reported to their professional bodies (Portfolio Committee on Correctional Services 2008). More recent figures indicate that 701 officials were investigated for medical aid fraud. ${ }^{2}$ The services of the SIU do, however, not come free of charge and under the first agreement the DCS paid the SIU between $\mathrm{R} 5,5 \mathrm{~m}$ and $\mathrm{R} 6 \mathrm{~m}$ per year. Under the second agreement the costs escalated to R10m per year.

The SIU provides the DCS with specialist skills to provide integrated forensic solutions relating to forensic audits and investigations; remedial legal action; and systemic improvements and risk management. Importantly, the SIU is a state institution, which means that the state avoids the more expensive option of subcontracting the private sector for such services. Despite the escalating costs, there is really no alternative at this stage. The costs incurred are also dwarfed by the size of the DCS budget (R11,67b for 2008/9). At less than 0.1 per cent of the department's 2008/9 budget, the R10m per year spent on the SIU is a wise investment and yields reasonable returns for the state.

Even though public reports on the SIU's investigation results may be perceived by some to be detrimental to the department's public image, they nonetheless communicate the clear message that something is in fact being done about corruption. Unfortunately, recent media reports not only failed to make this point, but also failed to describe the systemic achievements facilitated by the SIU's involvement with the DCS. Increased transparency can, in the long run, only benefit the department's public image.

\section{Departmental Investigating Unit}

The Departmental Investigating Unit (DIU) was established in 2004 to meet the minimum anticorruption capacity requirements developed by the Department of Public Service and 
Administration (DPSA 2006). From the initial four investigators appointed, it has now grown to 18 investigators drafted from the SIU, SARS, Directorate Special Operations in the NPA, and the SAPS Organised Crime Unit. The capacity of the DIU is in the process of being further increased with 75 of a targeted 500 investigators trained to assist at regional level. ${ }^{3}$ Upon completion of investigation, cases from the DIU are referred to the Code Enforcement Unit of the DCS for disciplinary action. The results have been equally impressive with a conviction rate of 98 per cent over the past two years, involving more than 100 cases. $^{4}$

\section{CHALLENGES AHEAD}

Fighting corruption in the prison system is not without challenges and the following will highlight a number of these. The work of the SIU and DIU has demonstrated the successes possible with investigations aimed at fraud and corruption where the state had lost or stands to lose large amounts of money. The challenges described below emanate from the other pillars of an effective anti-corruption strategy, namely prevention, public awareness, and institution building.

\section{SUSTAINED DISCIPLINARY ACTION}

Given the findings of the Jali Commission and the work of the SIU one would have expected a consistent, if not growing, trend in disciplinary actions against DCS officials, resulting in a significant proportion of dismissals. The increase in the number of DCS officials (from 30199 in 1998 (DCS 1999:39) to 40795 in 2006/7 (D CS 2007:140)) should also have been reflected in a natural increase in the number of disciplinary sanctions. Trends in disciplinary sanctions imposed, however, suggest differently, as shown in Figure $1 .^{5}$ The most obvious is the see-saw figure in total disciplinary sanctions imposed, from more than 2600 in 1998, dropping to 1061 in the following year but climbing to just below 2500 in 2000/1. The high number of disciplinary actions during 1997 and 1998 were the result of the investigations undertaken by the Public Service Commission (PSC) and the DPSA. The spike in 2001-3 can be attributed to the early work of the Jali Commission and the SIU. During the first three years of the SIU's involvement in the DCS (2002-2005), the total number of disciplinary actions dropped to a meagre 224 cases in 2004/5, but the fruits were harvested the following year when disciplinary sanctions climbed to 1850 , the highest level since 1998. These were cases

\section{Figure 1}

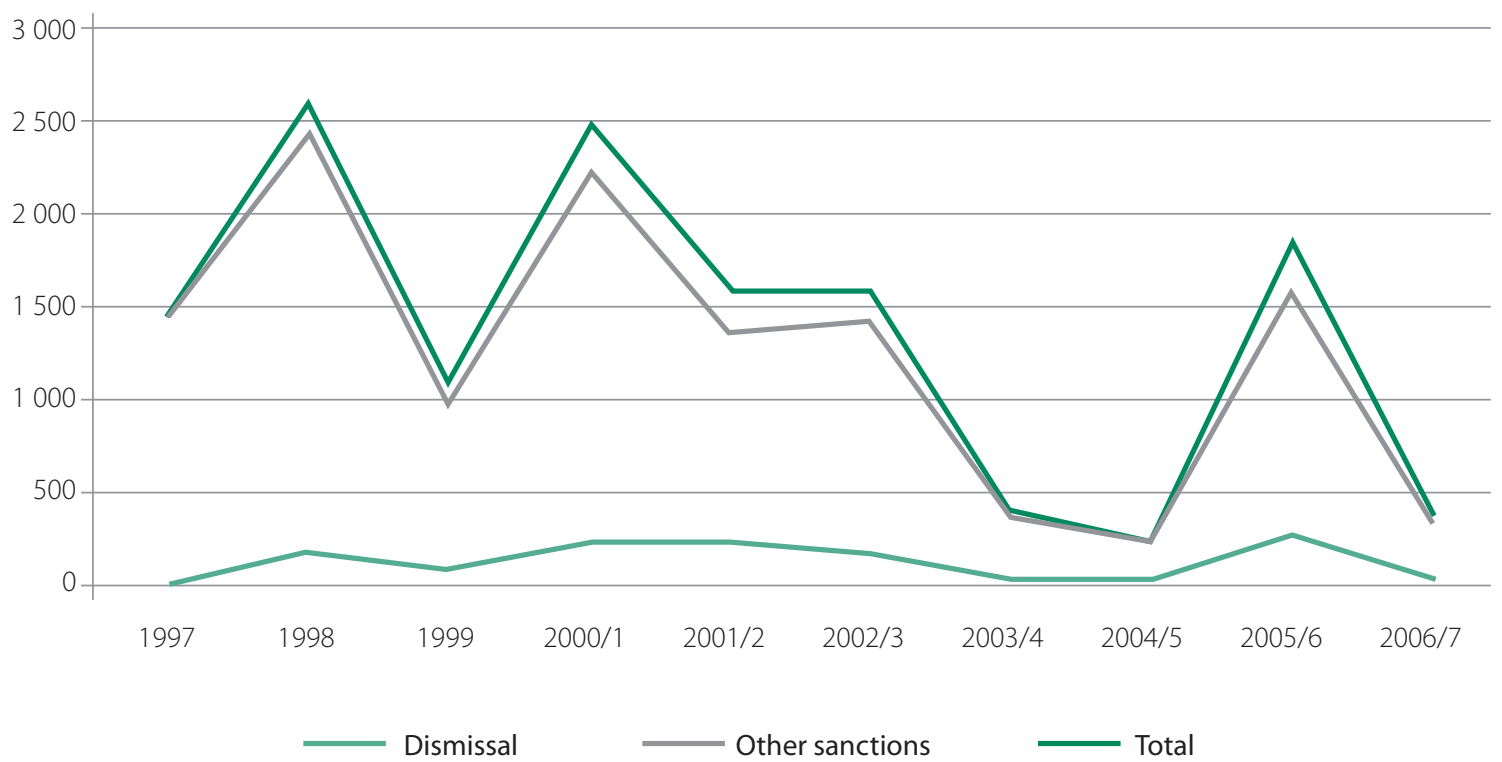


primarily related to medical aid and social grant fraud.

Dismissals, however, remain a rare event in the DCS. The highest number of dismissals was 264 in $2005 / 6$, or 14 per cent of total disciplinary sanctions imposed. In the following year, 2006/7, the total number of disciplinary actions dropped to 367 with only 33 dismissals.

The see-sawing in the number of disciplinary actions taken against employees of the department may reflect an attitude, or even a decision, by DCS management that the 'SIU and DIU will take care of discipline'. If this is indeed the case, it is extremely unfortunate. The two investigating units are there to support the DCS with specialist skills and knowledge and to provide comprehensive forensic solutions, but they do not replace the dayto-day duty of every manager in the department to enforce the disciplinary code and promote good performance. Enforcement of the disciplinary code by every operational manager also lends sustainability to the achievements of the investigations into corruption and maladministration, by making compliance with prescripts and codes part of organisational culture.

\section{MAKING THE ACHIEVEMENTS PART OF BUSINESS AS USUAL}

Many of the problems relating to corruption and maladministration that the DCS has faced over the past ten years have their roots in poor systems and inadequate controls. This, therefore, forms an important focus area of the SIU's interaction with the department. Particular risks identified in this regard are lack of internal controls; inadequate asset management; and lack of effective monitoring and evaluation systems (Portfolio Committee on Correctional Services 2008).

Addressing these issues is difficult as the department is complex: it has 237 prisons, a staff corps in excess of 40000 , an estimated 360000 people circulating through the prison system annually, and it is highly dependent on service providers for goods (e.g. food and material). The fact that the department had received five consecutive qualified audits by 2006/7 (a feat shared only by the Department of Home Affairs) is indicative of the challenges faced by the department and its inability to deal with them.

The 2006/7 DCS Annual Report reflects a number of key outputs related to improving governance that were not achieved or partially achieved, whilst others were fully achieved. Although the asset register was not completed, 970 officials were trained in financial and supply chain management, yet this positive achievement was offset by the fact that the newly trained officials were apparently not deployed (DCS 2007:25). On the other hand, a baseline of risks was established, and 60 disciplinary hearings related to fraud and corruption were held, with a 92 per cent conviction rate. Vetting of departmental staff turned out to be a major challenge and of the 500 forms submitted to the NIA for vetting, only 290 were completed. The DCS has also developed numerous (21) policies aligned to the White Paper on Corrections but only five per cent of targeted managers were trained in these policies.

In short, while progress has been made, changing the direction and the culture of such a large organisation is not easy, especially one that has significant historical baggage. Accurate strategic planning with achievable targets must map the path ahead and it will primarily be up to Parliament, by means of the Portfolio Committee on Correctional Services, to see that these are indeed achieved. In this regard it can draw on the Department of Public Service and Administration and the Public Service Commission as the technical experts in building a clean and effective DCS.

\section{CORRUPTION AND THE TREATMENT OF PRISONERS}

The Jali Commission had a real and substantive expectation that the Office of the Inspecting Judge would be more active in combating corruption. It was disappointed that this oversight structure failed to use its powers to conduct its own investigations and to hold, for example, a 
Commission of Inquiry as it is mandated to do (Correctional Services Act 1998:S90 (5) \& (6)). Correctly, the Commission saw the treatment of prisoners as inextricably linked to corruption.

A 2001 amendment to the Correctional Services Act saw the removal of the power to inspect and report on 'corruption and dishonest practices' from the mandate of the Judicial Inspectorate (Act 32:2001:Section 31). The Jali Commission regarded this amendment as ill-conceived (Jali Commission 2006:587). The fact that reporting on 'corruption and dishonest practices' remained within the mandate of the Inspecting Judge of Prisons (JIOP) was in all likelihood the result of an omission on the part of the drafters of the amendment. The first version of the Correctional Services Amendment Bill (B32 of 2007) attempted to remove the power of the Inspecting Judge, but this failed and the final version of the Bill adopted by Parliament retained the power of the Inspecting Judge to report on corrupt and dishonest practices. During the deliberations on the Bill it was clear that civil society, the Portfolio Committee and the Judicial Inspectorate were in agreement with the Jali Commission that the treatment of prisoners is indeed 'inextricably linked to corruption'.

While the SIU and the DIU have focused on grand corruption, very little has been done to address the so-called petty corruption that takes place in prisons daily. When a prisoner has to pay R10 for an extra blanket in winter or R2 to make a phone call, it may sound like petty corruption, but seen across the entire prison system and adding up all the R10 and R2 payments, it is not so 'petty'. Moreover, the impact of such practices on prisoners who do not have enough money to pay the bribes is far in excess of their monetary value. Current efforts to address this type of corruption in the prison system have not been particularly successful and have not been a focus of the SIU, DIU or the JIOP.

Creating an environment where prisoners feel free to report corruption without fear of reprisal appears to be very difficult. The JIOP recorded a mere 398 complaints from prisoners alleging corruption in 2007/8 (Office of the Inspecting Judge 2008:17) and 1463 in 2005/6 (Office of the Inspecting Judge 2006:11). ${ }^{6}$ The PSC's National Anti-Corruption Hotline received only 21 complaints involving the DCS in 2006/7, after it received 141 complaints involving the DCS the previous year (Public Service Commission 2007:13).

Responding to these complaints presents a further challenge. Presumably these can be dealt with by the DIU. However, with 18 investigators for the entire department, it is too small to deal with the problem adequately (Muntingh 2006:21).

Developing a mechanism to effectively investigate allegations of corruption from prisoners remains a significant shortcoming in the strategic response to corruption. Hopefully the additional 500 regional officials being trained in investigation will assist in this.

\section{PUBLIC REPORTING}

Reporting on the investigation of corruption in the DCS has been scant and the most comprehensive report remains that of the Jali Commission. Even the SIU reports only provide cursory details, leaving many questions unanswered as to the exact facts of the cases handled. Apart from holding offenders accountable, investigations into corruption should contribute to the broader process of prevention in a number of ways:

- Investigations should build knowledge by improving understanding of how a particular crime was committed, how it was detected and what effect it had; and indicate systemic weaknesses.

- Investigations should inform the risk assessment with reference to type of risk and the extent of the risk.

- The results of investigations, successful or not, should be made available to stakeholders from government or civil society with the aim to improve insight into the problem and to demonstrate that effective action can and will be taken against corrupt officials. 
The New South Wales Independent Commission against Corruption (ICAC) regularly makes the results of its investigations public in the form of comprehensive reports. The reports are detailed, providing not only a description of the offence in question but also the history of the offence(s), giving particular insight into the chain of events preceding the offence and context in which it occurred. It is also noteworthy that the reports are available relatively soon after the investigation has begun, often with interim reports being followed by more comprehensive reports at a later stage; both interim and final reports are made public. ${ }^{7}$

Apart from making reports available in the public domain, the results of investigations ought to be reported to key stakeholders, such as the oversight institutions of Parliament, and in particular the Portfolio Committee on Correctional Services and the Standing Committee on Public Accounts (SCOPA). Given the particular history of the department and the findings of the Jali Commission, there is a strong argument to be made for specialised, regular and structured reporting to Parliament on progress made in addressing corruption.

Moreover, investigations must be communicated to the staff of the department to demonstrate that action has been taken and to provide staff with a deeper understanding of the risks presented by their work environment. Investigations have a strong symbolic value that should be capitalised on. Publishing the full results of investigations would also serve to stimulate the discourse on ethics and integrity among the staff corps. In short, there are several reasons why the findings of investigations should be made widely available, not only because this is required in terms of reporting duties, but also to create awareness and develop understanding among the staff of the department.

\section{CONCLUSION}

An organisation with more than 40000 employees and a 'customer base' with a known history of criminal involvement pose significant challenges from a governance and corruption perspective. In the aftermath of the Jali Commission it appears that the DCS has put in place the basic investigative measures to combat corruption. It also appears that systemic improvements are ongoing and that this will in due course limit the opportunities for corrupt officials. According to the DCS the work of the SIU and the DIU enjoy the support of officials in general and that there has been a positive change in the reporting of corruption. ${ }^{8}$ Challenges appear to be at operational level and more particularly with managers who seem to be reluctant in enforcing discipline and compliance with the relevant codes. It is indeed the indulgence by managers of minor transgressions, and their passivity, that pose the greatest risk to harvesting the fruits of six years of active investigations by the SIU and the DIU.

\section{REFERENCES}

Correctional Services Act 1998 (Act No. 111 of 1998)

Correctional Services Amendment Act 2001 (Act No. 32 of 2001)

De Lange, D 2008. Endemic nature of corruption. IOL [online] 21 May. Available from http://www.iol.co.za/ index.php?set_id=1\&click_id=15\&art_id=vn200805210 55328977C816999 [accessed 22 August 2008]

Department of Correctional Services 1999. Annual Report 1998.

Department of Correctional Services 2007. Annual Report 2006/7.

Department of Public Service and Administration 2006. Anti-Corruption Capacity Requirements: Guidelines for implementing the Minimum anti-corruption capacity requirements in departments and organisational components in the public service. Available from http://www.dpsa.gov.za//macc/ Anti\%20Corruption\%20Capacity_Booklet.pdf [Accessed 13 August 2008]

Du Plessis, C 2006. Tender gekonkel oopgevlek. Die Burger [online] 26 July. Available from http://152.111.1.251/ argief/berigte/dieburger/2006/11/16/DB/8/abdkd2.html [accessed 22 August 2008]

Final Report of the Judicial Commission of Inquiry into Allegations of Corruption, Maladministration and Violence in the Department of Correctional Services 2006.

Minutes of the Portfolio Committee on Correctional Services of 20 May 2008, PMG. Available from http://www.pmg.org.za/report/20080520-briefing- 
special-investigations-unit-investigation-department [accessed 22 August 2008]

Muntingh, L 2006. Corruption in the prison context. CSPRI Research Report 11:19

Muntingh, L 2006. Investigating Prison Corruption in South Africa. CSPRI Research Report 12:6

Nötzel, M 2002. Investigation Strategies and Tactics in the prosecution of corruption offences: experiences from Germany. In C Fijnaut and L Huberts (eds), Corruption, Integrity and Law Enforcement, The Hague, Kluwer Law International.

Office of the Inspecting Judge 2006. Annual Report of the Judicial Inspectorate of Prisons 2005/6. Cape Town.

Office of the Inspecting Judge 2008. Annual Report of the Judicial Inspectorate of Prisons 2007/8. Cape Town.

Pope, J 1999. Elements of a successful anti-corruption strategy. In R Stapenhurst and SJ Kpundeh, Curbing corruption - toward a model for building national integrity. Washington: Economic Development Institute of The World Bank.

Public Service Commission 2007. Trend Analysis on Complaints Lodged with the Public Service Commission during the 2006/2007 Financial Year, Pretoria.

Van der Beken, T 2002. A Multi-disciplinary approach for detection and investigation of corruption. In C Fijnaut and L Huberts (eds), Corruption, Integrity and Law Enforcement. The Hague: Kluwer Law International.

\section{ENDNOTES}

1 See Proclamation R 44 dated 28 November 2007 for a full description.

2 Interview with Director of the DIU, 12 August 2008

3 Interview with Director of the DIU, 12 August 2008

4 Interview with Director of the Code Enforcement Unit, 12 August 2008

5 The data used in Figure 1 was extracted from the various annual reports of the DCS of the period covered. It should be noted that the report for 2000/1 covers a 15-month period when the department changed its reporting period from a calendar year to a financial year.

6 Note that in the 2006/7 Annual Report of the JIOP the breakdown of complaints received is not provided.

7 See ICAC Investigation into the Department of Corrective Services: Fourth report - Abuse of official Power and Authority, November 1999 and ICAC Report on the investigation into the introduction of contraband into the Metropolitan Remand and Reception Centre, Silverwater, September 2004.

8 Interview with Director of the DIU, 12 August 2008 